\title{
The Challenge of the New Feminist Generation in Saudi Arabia
}

\author{
Dr Ibrahim Abdel Latif Shalabi \\ University Of Hail, Hail Saudi Arabia
}

\begin{abstract}
Several researchers in the past studied the challenges and opportunities feminism can bring forward by making this topic the centre of attention and verbalizing more about it. The religion of Islam has not in any way regarded women to be superior than men but feminism does not demand or talk about superiority. It is based on asking for equal rights that women deserve in terms of education, employment, socialism, decision making, driving, wearing clothes, putting on make-up, achieving higher posts in life and such. Qualitative research method is used in this study which includes the collection of data from secondary sources. The inductive approach is used which includes studies and some observations made in the past years. The results of this study indicate that the new feminist generation in Saudi Arabia is more focused and dedicated in breaking the glass ceilings from their lives and demanding those ethical opportunities that can help females become what they wanted to be and earn a source of livelihood enough to support their own independent lives. Women who are stronger and capable do not need the assistance of a man that only comes in their life to impose restrictions after marriage and stops them from earning finances or reaching optimum heights. Islam is a beautiful religion which states to treat women with respect and dignity, not to cut their wings and make them kill their dreams in the name of religion, which does not support cruelty in any way on the part of females.
\end{abstract}

Keywords: Feminism, Females, Islam, Socialism, Qualitative.

DOI: $10.7176 /$ JLLL/74-02

Publication date: December $31^{\text {st }} 2020$

\section{INTRODUCTION}

The word feminism has several meanings attached to its core. It cannot be stated in a single definition as people have different opinions regarding its subject matter (Harding, 1986). There are approximately 7 billion people residing in this world, born in distinctive cultures, values, traditions, races, languages, economic lifestyles, color, casts and social classes. Every individual is born with a different thinking pattern from the other because of the fact that the person views certain circumstances in such a manner which no one has paid attention to, before. This phenomenon considers those thinkers who generate innovative ideas as someone who is able to change the ongoing dynamics. Several people have brought forward their efforts in shaping the mindsets of the general public by becoming philosophers, theorists, motivational speakers and orators. These people are responsible for transforming the thinking criteria of the population and making them perceive that women are to be kept at homes to do the household chores, feed the children and look after their families. This living pattern was adopted and followed for decades, women were supposed to attend to all the work imposed on them by their husbands who went out to find employment whereas the females were not allowed to leave the house unless it was an emergency (Sanday, 1981).

Discrimination because of color among women was also quite common in which black women all belonged to the poor community and had to visit different homes of the white families where they were hired as maids and were treated unfairly if they did not do the house chores well. The life of black women has been hard and cruel; they were forced to obey the orders of the white people and their husbands, or else they were divorced and kicked out. Being divorced was for women both a stigma and an existential issue. The concept of feminism arose in the early $19^{\text {th }}$ and $20^{\text {th }}$ century, bringing about a massive turning wave in the peoples believes and past practices (Delmar, 1986).

\section{LITERATURE REVIEW}

The economy of Saudi Arabia is based on male dominancy as they have more rights in contrast with the females. Saudi women may have the right to enter politics, but until recently, they have not been allowed to drive cars to go to work and perform the job duties. However, a recent law campaign has been passed by King Salman which declares that females are now allowed to drive their cars freely whenever they want (Shmuluvitz, 2011). This law was laid down after numerous debates, arguments, clashes and disputes, brought forward by various Islamic scholars in which they claimed that giving women equal rights is against Islamic jurisprudence and the religion itself, though some specific extensions can be made in which letting the women drive cars and roam around without having to wear Burqa at all times should be worked on. Women in Islam are instructed to wear hijab and they should not raise their voice for something which cannot be solved or changed. Therefore, hijab is mandatory to wear, but ban on driving cars has been removed. This step opened doors for females in wider areas where they were not able to reach before because of the restricted environment of Saudi Arabia that demotivated women to 
verbalize about equal rights.

The employment rate of women in Saudi Arabia is just $15.4 \%$ which displays a gap of employment encouragement among the female population and possibly a glass ceiling for them (Rajkhan, 2014). The notion of glass ceiling was specifically made to target the women who wanted to achieve greater heights for their expertise and dedication towards their job roles but were restricted to do so due to the invisible glass ceiling which stopped them from having higher designations during employment. According to Alsuwaigh (1989), this practice has affected thousands of women throughout the globe whose dreams, goals and interests were career-oriented but were fated to founder on the past prevailing mode of conduct.

On the other hand, new feminist generation in Saudi Arabia has actively took part in discussing with the concerned authorities their rights to get employment freely for higher positions along with allowing them to participate in sports, make big decisions on their own if the males in the family are not willing to listen but it is for the female's justice and wellbeing and the right to do shopping without the limitations of trying on clothes (Yamani, 2005).

\section{METHODOLOGY}

The methodology of this article focuses on different research techniques and approaches utilized to perform the research and generate possible outcomes. According to the nature of the following article, the qualitative research methodology is used to conclude the study. Qualitative research method is the type in which detailed explanations on the study topic along with knowledge and understanding are mentioned to carry forward the study. The information used in qualitative procedure is comprised of secondary sources that involves the internet, books, newspapers, websites, past research papers and such. The information is extracted from these secondary sources to fulfill the objective.

Research philosophy is linked with defining the way the gathered data is related to the content matter of this research. The common forms of research philosophies are comprised of interpretivism, positivism, objectivism, and realism (Abeyasekera, 2003). In the following research, the positivism research philosophy is adopted. Positivism method consists of the data which is defined in qualitative aspect with the assistance of inductive approach. Positivists consider that the occurrence of the collected data should be insulated and interpretation should be replicated. This led to the manipulation of objects into different variables and research techniques that are widely used by various research analysts (Collins, 2010). Also, positivism philosophy is based on the information that can be gathered through observations and cognition as it can be achieved through critical analyses.

There are mainly two disparate kinds of data collection strategies followed, for which the secondary sources are evaluated and qualitative one is chosen for this work (Sharon \& Carol, 2007). In order to perform research appropriately and effectively, different research instruments are examined that can be used. In the following qualitative research, secondary data and inductive approach is utilized to construct the structure of this work and to elaborate it.

\section{RESULTS}

Saudi feminist generation has taken part in social and economic prospects of the country. They are becoming the new professors, doctors, social workers, bank directors, journalists, college deans, mathematicians, scientists, and shop keepers (Bahry, 1982). Twenty-five years from now, women residing in Saudi Arabia would not have imagined that they could become radio announcers, school directors and journalists because it is known that the economy does not allow women to pursue careers in these fields as it may jeopardize the Islamic Sharia on their part. As per a study conducted on the Saudi economy, young women have more options than the older ones in some educational fields, rights to property and divorce. Islamic feminism is one response; criticisms of strict segregation are also common. The new feminist generation has to unite for the purpose of convincing their elders to allow both sexes to mix socially before marriage as females believe that arranged marriages can be held but it is necessary to let them talk with their future spouse before anything gets fixed so that they can know if they will develop an understanding with the person or he is not what they want as a husband (GB, 2000). In some families, this aspect can be seen but in the other half of the families' females are not in the position to question their parents regarding this sensitive issue.

Mir-Hosseini (2006) exclaimed that it is a challenge for the feminist generation in Saudi Arabia not to opt for those living styles that are Western in the name of modernity and equal rights, but as the economy is progressing in this regard and new foreign immigrants have increased so the inevitability of this factor has grown. This can either impact the overall country negatively or raise some serious allegations for excluding them to protect Islam. As Saudi Arabia is an Islamic state therefore, having faith in the oneness of God and following the Quran and Sunnah is essential. Basic liberties and modes of entertainment are limited for Saudi women. Hence, the upcoming feminist generation may want to alter the existing standards and rules in relation to employment, sports, publiclife, marriage, entertainment and social work opportunities that were initially set by the Kings and persuade them 
to think in a different manner which is in favor of the females (Doumato, 1999).

\section{CONCLUSION}

Feminism refers to women rights and equality; it associates females as an equivalent to the male women cannot be considered to be equal to men in most of the aspects like fertility, marriage, polygamy, decision making and such. Besides these characteristics, arguing on this topic takes strength and courage for the women as they are raising their voice for something which holds importance to them. Female driving was banned in Saudi Arabia since the establishment of the Kingdom because it was perceived as a cause for attraction to males, hence harassment. In order to protect women from physical abuse, a number of constraints were created for all Saudi women to follow, but the new feminist generation is debating on the past limitations and want to live a life equally as men in some aspects not all. Some of those aspects can be looked after and discussed by the Saudi government to reshape the previous standards at a specific extent that can enable more opportunities for women who want to grow and develop are goal-oriented.

All in all, gender inequality can be easily witnessed in the country as it is a prevailing situation which has to stop at a certain level. Feminism and Islam are two distinctive elements that can be intertwined but nothing of greater value can come out it as the Islamic principles regarding women rights have been designed for the sole benefit of the female gender, trying to find ways to modify them and add extensions can waver the whole religious perspective and beliefs.

\section{References}

Abeyasekera, S. (2003). Qualitative Analysis Approaches to Qualitative data: Why, When \& How. Journal of Participatory Research Methods, Implementation, Effectiveness, and Institutional Context.

Alsuwaigh. (1989). Women in transition: The case of Saudi Arabia. Journal of Comparative Family Studies, 6778.

Bahry. (1982). The new Saudi woman: Modernizing in an Islamic framework. Middle East Journal, 502.

Collins, H. (2010). "Creative Research: The Theory and Practice of Research for the Creative Industries". AVA Publications.

Delmar. (1986). What is Feminism?

Doumato. (1999). Women and work in Saudi Arabia: how flexible are Islamic margins? The Middle East Journal, $568-583$.

GB, Y. a. (2000). Changed identities: The challenge of the new generation in Saudi Arabia. London: Royal Institute of International Affair.

Harding. (1986). The science question in feminism. Cornell University Press.

Mir-Hosseini. (2006). Muslim women's quest for equality: Between Islamic law and feminism. Critical inquiry, 629-645.

Rajkhan, S. F. (2014). Women in Saudi Arabia Status, Rights, and Limitations. University of Washington Bothell.

Sanday. (1981). Female power and male dominance: On the origins of sexual inequality.

Sharon, C., \& Carol, B. (2007). Qualitative Research Designs. In C. Sharon, \& B. Carol, Introduction to Nursing Research (pp. 171-183).

Shmuluvitz. (2011). The Saudi women2drive campaign: just another protest in the Arab Spring? Tel Aviv Notes, 1-4.

Yamani. (2005). Aspirations of a new generation. Women and Islam: Images and realities, 402. 